\title{
Isolation of Chlamydia using McCoy cells and Buffalo green monkey cells
}

\author{
PJ WILLS, L JOHNSON, RG THOMPSON \\ From the Public Health Laboratory, New Cross Hospital, Wolverhampton WV10 0QP
}

SUMMARY Unselected eye and genital specimens from 233 patients were cultured for Chlamydia. The isolation rates were compared using McCoy cells and Buffalo green monkey cells, both procedures being performed with and without the addition of cycloheximide and centrifugation. No signficant difference was found in the isolation rates using the four methods. The characteristics of the two cell lines and the advantages of omitting cycloheximide treatment and centrifugation are discussed.

A Buffalo green monkey continuous kidney cell line for the laboratory diagnosis of Chlamydia trachomatis infection has recently been described.' We have compared these cells with the more commonly used McCoy culture cells in our routine processing of clinical specimens. The Buffalo green monkey cells were stated to have certain advantages; in particular, the cytoplasmic inclusions were more conspicuous than those produced in McCoy cells. We have used McCoy cells successfully since 1971 to investigate genital and eye infections. Since 1977 we have used a procedure that requires neither the use of cycloheximide nor centrifugation. ${ }^{2}$ We wished to see whether Buffalo green monkey cells compared favourably with McCoy cells in our laboratory, using our procedure and the more commonly used procedure which includes cycloheximide treatment and centrifugation.

\section{Material and methods}

After preliminary experiments with a laboratory adapted strain of Chlamydia, we compared four methods of Chlamydia culture from clinical material using the two cell lines either with or without both cycloheximide treatment and centrifugation. The methods were examined to compare not only the Chlamydia isolation rates but also the cultural and microscopic features of the cells and the technical ease of the procedures. Unselected eye specimens from 101 patients and genital specimens from 132 patients were examined using the four methods. The

Accepted for publication 25 October 1983 eye swabs were from patients with suspected inclusion conjunctivitis (neonatal or adult) or trachoma and from family contacts of trachoma. The gynaecological patients included inpatients and outpatients for whom Chlamydia culture was requested. The patients from the sexually transmitted disease clinic included cases of urethritis or cervicitis, asymptomatic contacts, and checks following treatment.

Specimens were received in $1.5 \mathrm{ml}$ transport medium ${ }^{3}$ and kept at $4^{\circ} \mathrm{C}$ before inoculation or frozen at $-70^{\circ} \mathrm{C}$ if this was to be delayed more than 48 $h$. Cell culture was in flat bottomed tubes containing circular coverslips (10 mm diameter) and $1 \mathrm{ml}$ cell suspension in Eagle's minimal essential medium (Hanks based) including $10 \%$ fetal calf serum and $100 \mu \mathrm{g} / \mathrm{ml}$ vancomycin. All incubations were at $37^{\circ} \mathrm{C}$ in $5 \% \mathrm{CO}_{2}$.

For the centrifugation-cycloheximide technique the cell monolayer was prepared by overnight incubation of a suspension of 100000 cells followed by replacement of the fluid with fresh medium. After adding $0.2 \mathrm{ml}$ of transport medium containing clinical material the tubes were centrifuged at $1900 \mathrm{~g}$ for $1 \mathrm{~h}$ and left for $2 \mathrm{~h}$ at $37^{\circ} \mathrm{C}$; the supernatant was replaced with $2 \mathrm{ml}$ of medium containing $2 \mu \mathrm{g} / \mathrm{ml}$ cycloheximide and $20 \mu \mathrm{g} / \mathrm{ml}$ glucose and incubated for $48 \mathrm{~h}$. The concentration of $2 \mu \mathrm{g} / \mathrm{ml}$ cycloheximide has been claimed to be optimal for McCoy cells. ${ }^{4}$ Preliminary experiments in our laboratory have confirmed this, and we have found it also to be a suitable concentration for Buffalo green monkey cells infected with a laboratory strain of Chlamydia. After removal of the fluid the coverslips were washed and fixed with methanol, stained with 
Isolation of Chlamydia trachomatis from various clinical sources using four different methods

\begin{tabular}{|c|c|c|c|c|c|c|}
\hline \multirow{3}{*}{$\begin{array}{l}\text { Clinical } \\
\text { source }\end{array}$} & \multirow{3}{*}{$\begin{array}{l}\text { No of } \\
\text { patients examined }\end{array}$} & \multicolumn{5}{|c|}{ No of patients positive for chlamydia } \\
\hline & & \multicolumn{2}{|c|}{$\begin{array}{l}\text { Centrifuged with } \\
\text { cycloheximide }\end{array}$} & \multicolumn{2}{|c|}{$\begin{array}{l}\text { Uncentrifuged, } \\
\text { no cycloheximide }\end{array}$} & \multirow[t]{2}{*}{$\begin{array}{l}\text { Total all } \\
\text { methods }\end{array}$} \\
\hline & & McCoy & $B G M$ & McCoy & $B G M$ & \\
\hline $\begin{array}{l}\text { Eye } \\
\text { Gynaecological (high vagina } \\
\text { or cervix) }\end{array}$ & $\begin{array}{r}101 \\
33\end{array}$ & $\begin{array}{r}20(20) \\
3(9)\end{array}$ & $\begin{array}{r}15(15) \\
4(12)\end{array}$ & $\begin{array}{r}12(12) \\
4(12)\end{array}$ & $\begin{array}{r}15(15) \\
9(15)\end{array}$ & $\begin{array}{r}27(27) \\
6(18)\end{array}$ \\
\hline $\begin{array}{l}\text { STD clinic } \\
\text { Male urethra }\end{array}$ & 57 & $13(23)$ & $15(26)$ & $13(23)$ & $11(19)$ & $23(40)$ \\
\hline $\begin{array}{l}\text { Cervix } \\
\text { Total }\end{array}$ & $\begin{array}{r}42 \\
233\end{array}$ & $\begin{array}{r}7(17) \\
43(18)\end{array}$ & $\begin{array}{r}8(19) \\
42(18)\end{array}$ & $\begin{array}{l}10(24) \\
39(17)\end{array}$ & $\begin{array}{l}13(31) \\
44(19)\end{array}$ & $\begin{array}{l}15(3.6) \\
71(30)\end{array}$ \\
\hline
\end{tabular}

BGM = Buffalo green monkey; STD clinic: sexually transmitted diseases clinic. \% patients positive in parentheses.

Giemsa, mounted onto microscope slides, and examined with bright field microscopy. Dark field microscopy may have allowed more rapid scanning of the slides but was not used in this study. A magnification of 100 was used for scanning the slides, but higher magnifications were usually required to confirm the presence of chlamydial inclusions. The clinical diagnosis was not known to the observer at the time of examination.

For the simplified technique without centrifugation a suspension of 200000 cells in medium supplemeted with $20 \mu \mathrm{g} / \mathrm{ml}$ glucose was used. The McCoy cells were incubated for $30 \mathrm{~min}$ to $1 \mathrm{~h}$ before adding the clinical sample; the Buffalo green monkey cells were left for $1 \frac{1 / 2}{2}-3 \mathrm{~h}$. The tubes were then incubated for $48 \mathrm{~h}$ and the coverslips stained and examined as described above.

\section{Results}

The results are shown in the Table. The isolation rates obtained with the four methods were not significantly different $(\mathrm{p}>0.05$ for all comparisons using the $\chi^{2}$ test). The small apparent discrepancies are probably explained by the low number of infectious particles sometimes present in the inoculum-often very few chlamydial inclusions were seen in the stained cell monolayers. It is likely that any one of these methods, if used alone, would have given a higher isolation rate because a higher proportion of the clinical sample would have been inoculated.

\section{Discussion}

The Buffalo green monkey cells are therefore a suitable cell line for isolating Chlamydia from various clinical sources, giving an isolation rate equal to that obtained with McCoy cells. They have some interesting properties which may make them preferable to McCoy cells. They produce large and easily seen inclusions after several days' incubation, whereas the McCoy cell sheet is often destroyed after such a time by chlamydial multiplication. In the early stages of growth, however, we have found that inclusions are no easier to see in Buffalo green monkey cells than in McCoy cells. Indeed, the faster multiplication of McCoy cells may be an advantage when a rapid result is needed. A sample from the eye of a neonate with conjunctivitis produced visible inclusions after $18 \mathrm{~h}$ in uncentrifuged McCoy cells, but no inclusions were seen at this stage in Buffalo green monkey cells, although conspicuous inclusions subsequently appeared. Buffalo green monkey cells are easy to handle in the laboratory, and in our hands they have been subcultured for eight months without the spontaneous stripping from glass which is sometimes a troublesome feature of McCoy cells. They seem hardier than McCoy cells, and remain viable for longer without changing the culture medium. This study also shows that a high isolation rate for Chlamydia can be achieved in both cell lines without centrifuging the inoculated cell layer or adding cycloheximide. The absence of a centrifugation stage simplifies the method and allows specimens to be processed even if they arrive in the laboratory late in the working day.

We thank Flow Laboratories, Irvine, Scotland for their gift of the Buffalo green monkey cells.

\section{References}

' Hobson D, Lee N, Quayle E, Beckett EE. Growth of Chlamydia trachomatis in Buffalo green monkey cells. Lancet 1982;ii:872-3.

${ }^{2}$ Harper IA, Johnson L, Thompson RG. Culture of Chlamydia. J Clin Pathol 1982;35:365-6.

${ }^{3}$ Richmond SJ. The isolation of Chlamydia subgroup A (Chlamydia trachomatis) in irradiated McCoy cells. Med Lab Technol 1974;31:7-9.

${ }^{4}$ Ripa KT, Mardh P. Cultivation of Chlamydia trachomatis in cycloheximide treated McCoy cells J Clin Microbiol 1977;6:328-31.

Requests for reprints to: Dr RG Thompson, Public Health Laboratory, New Cross Hospital, Wolverhampton WV10 0QP, England. 
Dr Tebbutt replies as follows:

While I agree that the fluid used for the emulsification of haemophili can influence routine disc tests, I cannot accept that it accounted for the 25 strains wrongly identified by this method. I found that about $5 \%$ of $H$ influenzae strains, suspended in quarter-strength Ringer solution, grew on nutrient agar to which $\mathrm{V}$ but no $\mathrm{X}$ factor had been added. This percentage is similar to that found in routine disc tests when the haemophili were suspended in Nutrient Broth No 2. These results suggest that the presence of $\mathrm{X}$ factor in the agar medium is the most important consideration. Probably no complex medium which otherwise satisfies the growth requirements of Haemophilus spp is completely free from $\mathrm{X}$ factor.

I reported that growth of $H$ influenzae around a disc containing $\mathrm{V}$ factor was relatively common in routine disc tests, and this may be due to use of nutrient broth as the suspending fluid. Growth around the V disc, however, was usually considerably less than that around a combined XV disc. This permitted the correct identification of these strains.

Mrs Jones rightly draws attention to difficulties and problems of reproducibility with XV disc tests. My study suggests alternative methods for reliable identification of $\boldsymbol{H}$ influenzae in diagnostic laboratories.

GM TEBBUTT

Public Health Laboratory, South Cleveland Hospital, Middlesbrough, Cleveland TS4 3TA

\section{Book reviews}

Pre-Eclampsia. The Hypertensive Disease of Pregnancy. Ian MacGillivray. (Pp 392; £19.50.) WB Saunders. 1983.

This book is the work of a man who has devoted 35 years of his life to the study of pre-eclampsia. As such it bears the same relationship to published conference proceedings pertaining to this disease, of which there are many, as does a vintage premièr cru to supermarket plonk: it is balanced, mature, mellow, and rich.

Everything that anyone could possibly wish to know about pre-eclampsia can be found in this volume, and the author not only presents the many studies of his team in Aberdeen, but also reviews the literature with a keenly critical eye. The chapter on the pathological findings in this disease is excellent, and in it the author fully acknow- ledges and ungrudgingly praises the pioneering studies of Harold Sheehan.

The author records that in his youth he photographed the plaque on the wall in the Chicago Lying-In Hospital which still awaits the name of the discoverer of the cause of pre-eclampsia and notes that his early hopes and ambitions of seeing his name on that plaque have now receded. Many others have pondered that plaque but few have so little cause for disappointment as does Ian MacGillivray: he has produced a clear, wise, thoughtful, scientific book, one that all with even the slightest interest in pre-eclampsia will wish to have and treasure.

H FOX

Tumors: An Atlas of Differential Diagnosis. Cyril Toker. (Pp 484; £50.) Edward Arnold. 1983.

"Wallpaper matching" is a disparaging epithet applied by histopathologists to a certain means of diagnosis when conventional ones have failed. This atlas, consisting of monochrome photomicrographs of tumours classified entirely according to their histological pattern attempts to aid such a process. The small amount of text describes the morphological features but no other aids to diagnosis, eg clinical, are given. The photographic quality is very good apart from a tendency to high contrast. The author's terminology tends to be archaic, which is irritating and the verisimilitude of the work is compromised when one consistently sees "Exxner" in Call-Exner and "phylloides" in cystosarcoma phyllodes. I wonder if one is expected to refer to the atlas when seeing a common tumour in order to exclude the numerous similar-looking rarities which abound in it. In all justice to the author and prospective purchaser, I recommend that the latter spend five minutes looking at a copy in his bookshop and try to visualise how he would use the atlas before putting his $£ 50$ on the counter.

\section{Some new titles}

The receipt of books is acknowledged, and this listing must be regarded as sufficient return for the courtesy of the sender. Books that appear to be of particular interest will be reviewed as space permits.

Saunders Dictionary \& Encyclopaedia of Laboratory Medicine and Technology. Ed James L Bennington. (Pp 1674; £40.) WB Saunders Company. 1983.
Cell Fusion. Ciba Foundation Symposium 103. (Pp 291; £25.) Pitman Books. 1984.

Radiology of Inflammatory Bowel Disease. Clive I Bartram. Diagnostic Radiology Series. (Pp 310; £45.) Butterworths. 1983.

\section{Notices}

British Lymphoma Pathology Group Workshop on Lymphoproliferative Diseases

A British Lymphoma Pathology Group workshop on lymphoproliferative diseases will be held in Oxford from 26 to 28 September 1984 . The speakers include Professor Ron Dorfman, Professor Harald Stein, and members of the British Lymphoma Pathology Group. It is intended primarily for histopathologists.

Further details can be obtained from: $\mathrm{Dr}$ DY Mason, Department of Haematology, John Radcliffe Hospital, Oxford OX3 9DU.

\section{World Hemophilia AIDS Center}

The World Hemophilia AIDS Center (WHAC), an international clearinghouse of information about acquired immune deficiency syndrome (AIDS) and haemophilia, has been established at the Orthopaedic Hospital, Los Angeles, California. WHAC, established under the auspices of the World Federation of Hemophilia and Orthopaedic Hospital, will serve as an international case surveillance centre for AIDS or suspected AIDS cases in haemophilia patients. The Center also will distribute information about AIDS to concerned individuals and to organisations.

Further information can be obtained from: Shelby L Dietrich MD, World Hemophilia AIDS Center, Orthopaedic Hospital, 2400 South Flower, Los Angeles, California 90007.

\section{Correction}

An error occurred in the paper by Wills $e t$ $a l^{1}$ in the February 1984 issue. In the Material and methods section the concentration of glucose should have been given as $20 \mathrm{mg} / \mathrm{ml}$.

\section{Reference}

' Wills PJ, Johnson L, Thompson RG. Isolation of Chlamydia using McCoy cells and Buffalo green monkey cells. J Clin Pathol 1984;37:120-1. 